\title{
Correspondence
}

\section{Purported Mcl-1 inhibitor marinopyrrole A fails to show selective cytotoxicity for Mcl-1-dependent cell lines}

\author{
JM Eichhorn ${ }^{1}$, SE Alford ${ }^{1}$, CC Hughes ${ }^{2}$, W Fenical ${ }^{2}$ and TC Chambers ${ }^{*, 1}$
}

Cell Death and Disease (2013) 4, e880; doi:10.1038/cddis.2013.411; published online 24 October 2013

Subject Category: Cancer

\section{Dear Editor,}

Anti-apoptotic Bcl-2 family proteins Bcl-2, Bcl-xL, and $\mathrm{Mcl}-1$ have become prime targets for anti-cancer agents in an effort to overcome blocks in apoptosis exhibited by cancer cells. ${ }^{1}$ Marinopyrrole A, a marine natural product originally developed for its activity against Methicillin-resistant Staphylococcus aureus, ${ }^{2,3}$ was recently reported by Doi et al. ${ }^{4}$ to be a selective
Mcl-1 antagonist that binds to $\mathrm{Mcl}-1$ and targets it for degradation. This publication was received with great interest because the discovery of a specific Mcl-1 inhibitor had thus far eluded researchers. Indeed, the only agents reported to target $\mathrm{Mcl}-1$ to date are general transcription inhibitors, which show limited selectivity for Mcl-1 due to its short half-life. ${ }^{5,6}$ However, previous studies in human colon carcinoma cells reported actin
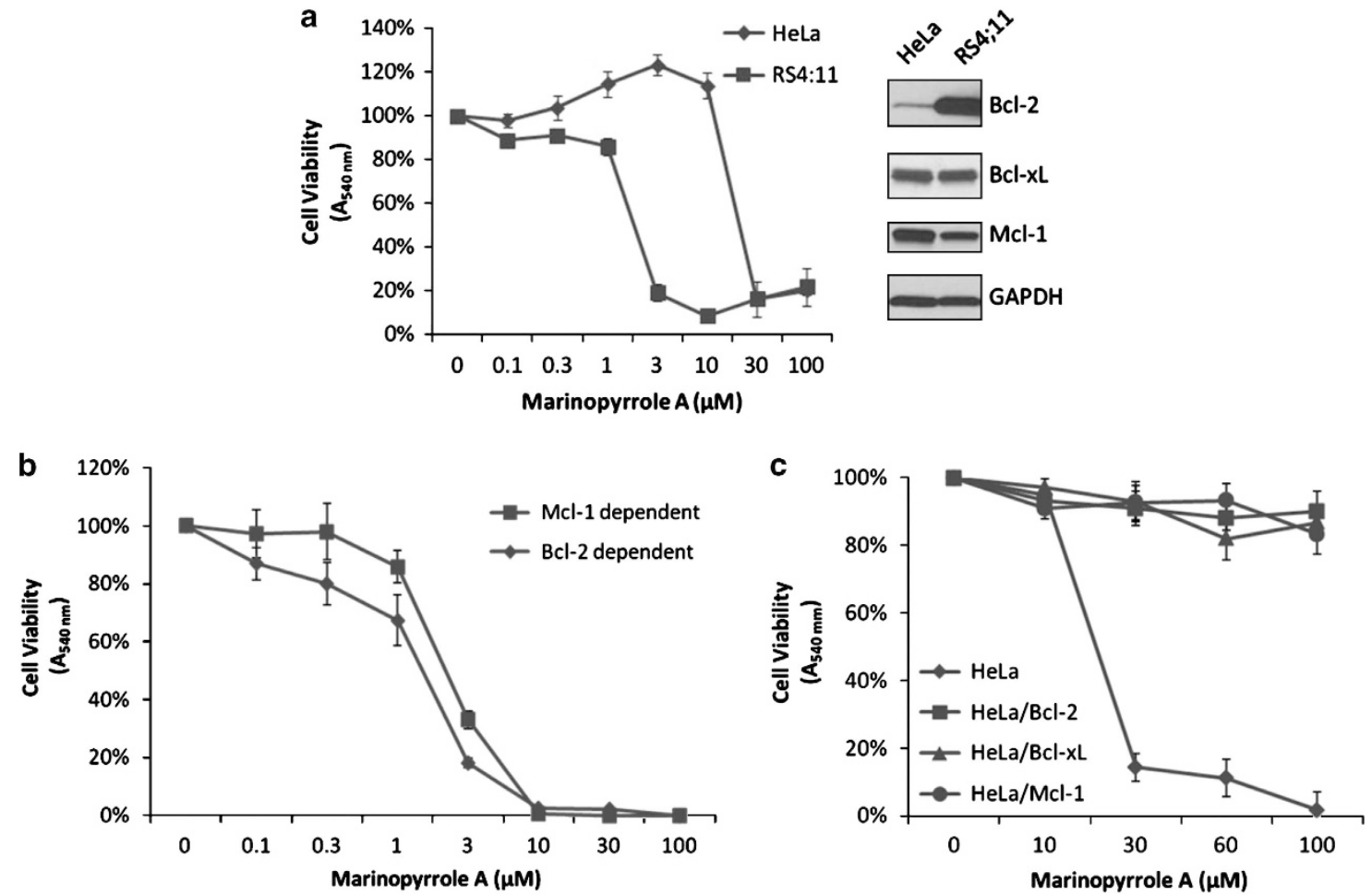

Figure 1 Marinopyrrole A is not selectively cytotoxic for Mcl-1-dependent cell lines. Cell viability was assessed using an MTT ((3-(4,5-dimethylthiazol-2-yl)-2, 5 -diphenyltetrazolium bromide) cell viability assay. Cells were untreated (100\%) or treated with marinopyrrole $\mathrm{A}(0.1-100 \mu \mathrm{M})$ for $72 \mathrm{~h}$. Results given are mean \pm s.d. ( $n=6$ ). (a) Left: cell viability curves for HeLa and RS4:11 (Bcl-2 dependent) cells. Right: immunoblot analysis of relative levels of anti-apoptotic Bcl-2, Bcl-xL, and Mcl-1. GAPDH was used as a loading control. (b) Cell viability curves for Mcl-1-dependent and Bcl-2-dependent leukemia cells. (c) Cell viability curves for control HeLa cells and HeLa cells generated to stably overexpress untagged full-length $\mathrm{Bcl}-2, \mathrm{Bcl}-\mathrm{xL}$, or Mcl-1. Cell extraction, immunoblotting, and cell viability assays using MTT dye were performed as described previously. ${ }^{9}$ Antibodies against Bcl-2 (sc-509) and Mcl-1 (sc-819) were from Santa Cruz (Santa Cruz, CA) and antibodies against Bcl-xL (2762) and GAPDH (14C10) were from Cell Signaling (Beverly, MA)

${ }^{1}$ Department of Biochemistry and Molecular Biology, University of Arkansas for Medical Sciences, Little Rock, AR, USA and ${ }^{2}$ Center for Marine Biotechnology and Biomedicine, Scripps Institution of Oceanography, University of California San Diego, La Jolla, CA, USA

${ }^{*}$ Corresponding author: TC Chambers, Department of Biochemistry and Molecular Biology, University of Arkansas for Medical Sciences, Mail Slot 516, 4301 W. Markham Street, Little Rock, AR 72205, USA. Tel: + 15016865755; Fax: + 15016868169; E-mail: chamberstimothyc@uams.edu 
as the primary target of marinopyrrrole $A{ }^{2}$ This raised the possibility that $\mathrm{Mcl}-1$ may not be the primary target for marinopyrrole $A$ in cancer cells. We therefore sought to determine whether marinopyrrole A was indeed a bona fidespecific Mcl-1 inhibitor.

Our recent studies testing the viability of HeLa cells after systematic knockdown of individual anti-apoptotic Bcl-2 proteins demonstrated strict dependence on $\mathrm{Mcl}-1$ (Eichhorn et al., manuscript submitted). We first compared the sensitivity to marinopyrrole of $\mathrm{Mcl}$-1-dependent HeLa cells versus RS4;11 human leukemia cells which have previously been shown to be dependent on Bcl-2 for survival. ${ }^{7}$ HeLa and RS4;11 cells were treated with increasing concentrations of natural marinopyrrole $A(0.1-100 \mu \mathrm{M})$ and cell viability assessed after $72 \mathrm{~h}$ (Figure 1a). Relative expression levels of $\mathrm{Bcl}-2, \mathrm{Bcl}-\mathrm{xL}$, and $\mathrm{Mcl}-1$ (Figure 1a, right) highlight $\mathrm{Bcl}-2$ overexpression in the $\mathrm{RS} 4 ; 11$ cell line. Surprisingly, marinopyrrole $A$ was much more effective against $\mathrm{Bcl}-2$-dependent $\mathrm{RS} 4 ; 11$ cells $\left(\mathrm{IC}_{50}: 2 \mu \mathrm{M}\right)$ when compared to $\mathrm{Mcl}-1$-dependent HeLa cells $\left(\mathrm{IC}_{50}: 20 \mu \mathrm{M}\right)$ (Figure 1a). Immunoblotting indicated that marinopyrrole A treatment did not affect $\mathrm{Mcl}-1$ expression levels (data not shown).

We next tested whether natural marinopyrrole A would show selective cytotoxicity against $\mathrm{Mcl}-1$ - versus $\mathrm{Bcl}-2$ dependent leukemia cell lines as reported by Doi et al. ${ }^{4}$ For this purpose we chose two murine leukemia cell lines generated from transgenic mice and established via multiple criteria to be either dependent on $\mathrm{Mcl}-1$ or $\mathrm{Bcl}-2 .^{8}$ Marinopyrrole $\mathrm{A}$ was equally effective against $\mathrm{Mcl}-1$-dependent leukemia cells $\left(I C_{50}: 2.5 \mu \mathrm{M}\right)$ as Bcl-2-dependent cells $\left(I C_{50}\right.$ : $2 \mu \mathrm{M}$; Figure 1b).

It is important to note that data presented by Doi et al. ${ }^{4}$ utilized a racemic mixture of synthetic marinopyrrole $A$, whereas our data and previous work done by Hughes et al. ${ }^{2}$ were performed using the natural $\mathrm{M}$-(-)-enantiomer. Therefore, cell viability assays were conducted in the Mcl-1- and Bcl-2-dependent leukemia cell lines using the non-natural $\mathrm{P}-(+)$-enantiomer, and no statistical difference between the two enantiomers was observed (results not shown).
Finally, we tested whether overexpression of Bcl-2, Bcl-xL, or $\mathrm{Mcl}-1$ would protect HeLa cells from marinopyrrole A. HeLa cells stably overexpressing $\mathrm{Bcl}-2, \mathrm{Bcl}-\mathrm{xL}$, or $\mathrm{Mcl}-1$ were treated with marinopyrrole $A$ for $72 \mathrm{~h}$ and cell viability was assessed. Strikingly, overexpression of each anti-apoptotic $\mathrm{Bcl}-2$ family member conferred complete resistance to marinopyrrole A (Figure 1c). Thus, marinopyrrole A failed to show selective cytotoxicity towards cells overexpressing Mcl-1 in contrast to previously reported data. ${ }^{4}$ The data in Figure $1 \mathrm{c}$ indicate that the death signals generated from marinopyrrole A activate the intrinsic apoptotic pathway.

The results reported here are in stark contrast to previously reported data showing that marinopyrrole $A$ induces cell death selectively in $\mathrm{Mcl}-1$-dependent but not $\mathrm{Bcl}$-2-dependent cells. ${ }^{4}$ While further studies are needed to establish the basis of this discrepancy, taken together, our results seriously question the validity of marinopyrrole $\mathrm{A}$ as a specific $\mathrm{Mcl}-1$ inhibitor.

\section{Conflict of Interest}

The authors declare no conflict of interest.

Acknowledgements. Thank you to $\mathrm{Dr}$. Anthony Letai for generously providing the Mcl-1- and Bcl-2-dependent cell lines.

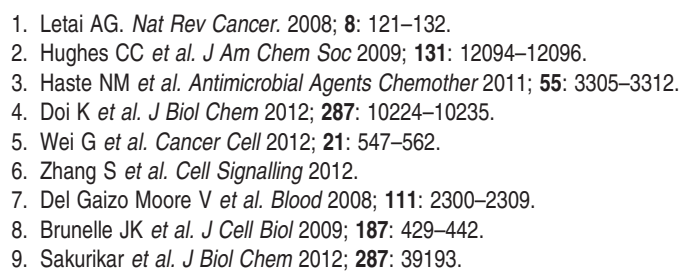

Cell Death and Disease is an open-access journal published by Nature Publishing Group. This work is licensed under a Creative Commons Attribution-NonCommercialNoDerivs 3.0 Unported License. To view a copy of this license, visit http://creativecommons.org/licenses/by-nc-nd/3.0/ 